\title{
Toxicity of Mimosa tenuiflora pollen to Africanized honey bees (Apis mellifera L.)
}

\author{
Toxicidade do pólen de Mimosa tenuiflora para abelhas (Apis mellifera L.) africanizadas
}

Carolina Vale da Silva', Luciene Xavier de Mesquita', Patrício Borges Maracajáa \& Benito Soto-Blanco' ${ }^{1}$

\begin{abstract}
Background: Mimosa tenuiflora (Willd.) Poir. (Mimosaceae) is a xerophilous plant which is very common in degraded areas in the Brazilian semi-arid region, including areas of beekeeping. The ingestion of leaves from M. tenuiflora by ruminants is responsible for malformations. Chemical analyses of this plant revealed that it contains several secondary compounds including three triterpenoidal saponins, designated Mimonosides A-C, four flavones, five flavanones and four chalcones. Several plant species contain secondary compounds in nectar and pollen that could be toxic to pollinators, including bees. Experimental approaches are necessary to identify plant species that produce pollen that is toxic to bees. The present study aimed to determine the toxic potential of M. tenuiflora (Willd.) Poir. (Mimosaceae) pollen to Africanized honey bees (Apis mellifera L.). Materials, Methods \& Results: The plant species utilized in this study was Mimosa tenuiflora (Willd.) Poir. (Mimosaceae) and a voucher specimen was deposited ( ${ }^{\circ}$. 9591) at the Dárdano de Andrade-Lima (MOSS) Herbarium, Universidade Federal Rural do Semi-Árido (UFERSA), Mossoró, RN, Brazil. Pollen samples were collected near Mossoró city, RN, in northeastern Brazil $\left(5^{\circ} 11^{\prime} 15^{\prime \prime} \mathrm{S}\right.$ and $\left.37^{\circ} 20^{\circ} 39^{\prime \prime} \mathrm{W}\right)$. Honeycombs that contained pupae of africanized honey bees (Apis mellifera) were collected from the apiary of UFERSA. Newly emerged forager bees, identified on basis of their body size and coloration, were used for the experiment. All the bees used were of the same age. Groups of twenty bees were put into wooden boxes $(11 \mathrm{x} 11 \mathrm{x} 7 \mathrm{~cm})$. The boxes were kept in an acclimatized chamber (BOD) at $32^{\circ} \mathrm{C}$ and $70 \%$ humidity. M. tenuiflora pollen was added to the food (5 parts of sugar mixed to one part of honey) at doses of 0 (control group; $n=195), 2.5 \%(n=178), 5.0 \%(n=186)$ and $10.0 \%$ $(\mathrm{n}=186)$. The bees were observed daily until the last one died. Statistical analyses were performed using a statistical software (GraphPad Prism v.4 for Mac). Median survival times, with 95\% confidence intervals, were estimated using Kaplan-Meier survival analysis. Differences in the time distributions between groups were tested for statistical significance using the logrank test. The median survival times of the bees were four days for all groups. Kaplan-Meier survival analysis revealed a significant difference $(\mathrm{P}=0.0041)$ between the survival curves, but the log-rank test did not show statistical difference $(\mathrm{P}=0.2825)$. The survival curve of controls differed $(\mathrm{P}=0.001)$ from the survival curve of the group fed $2.5 \%$ M. tenuiflora, but did not differ from the other groups.

Discussion: Several plant species contain secondary compounds in nectar and pollen that could be toxic to animals that consume them. Bees collect large amounts of pollen grains very efficiently, making these grains generally unavailable for pollination. Thus, presence of secondary compounds in pollen grains could be a strategy designed to restrict the loss of pollen to bees. Even though it contains several secondary metabolites, the results of the present study indicate that the ingestion of the pollen of Mimosa tenuiflora by Africanized honey bees (Apis mellifera L.) at conditions of the present study did not promote toxic effect.
\end{abstract}

Keywords: poisonous plants, toxic pollen, “jurema preta”, Mimosaceae, Hymenoptera, Apidae

Descritores: plantas tóxicas, pólen tóxico, jurema preta, Mimosaceae, Hymenoptera, Apidae.

${ }^{1}$ Departamento de Ciências Animais, Universidade Federal Rural do Semi-árido (UFERSA), BR 110 Km 47, CEP 59.625-900 Mossoró, RN, Brazil. ${ }^{2}$ Universidade Federal de Campina Grande (UFCG), Pombal, PB, Brazil. CORRESPONDENCE: B. Soto-Blanco [sotoblanco@ufersa.edu.br - Fax: +55 (84) 3315-1778]. 


\section{INTRODUCTION}

Mimosa tenuiflora (Willd.) Poir. (Mimosaceae) is a xerophilous plant which is very common in degraded areas in the semi-arid region of Brazil. However, the ingestion of leaves from M. tenuiflora is responsible for malformations (cleft lip, unilateral corneal opacity, ocular bilateral dermoids, buphthalmos with a cloudy brownish appearance of the anterior chamber due to an iridal cyst and segmental stenosis of the colon) in ruminants [8]. Chemical analyses of this plant revealed that it contains several secondary compounds including three triterpenoidal saponins, designated Mimonosides A-C, four flavones, five flavanones and four chalcones $[3,4,7]$.

Several plant species contain secondary compounds in nectar and pollen that could be toxic to pollinators, including bees [2,9]. Experimental approaches are necessary to identify plant species that produce pollen that is toxic to bees. In the present study, the toxic potential of the pollen of Mimosa tenuiflora was tested to Africanized honey bees (Apis mellifera L.).

\section{MATERIALS AND METHODS}

The plant species utilized in this study was Mimosa tenuiflora (Willd.) Poir. (Mimosaceae). A voucher specimen was deposited $\left(\mathrm{n}^{\circ} .9591\right)$ at the Dárdano de Andrade-Lima (MOSS) Herbarium, Universidade Federal Rural do Semi-Árido (UFERSA), Mossoró, RN, Brazil.

Pollen samples were collected near Mossoró city, $\mathrm{RN}$, in northeastern Brazil, (5'11'15"S and $37^{\circ} 20^{\prime} 39^{\prime \prime} \mathrm{W}$ ) at an altitude of $16 \mathrm{~m}$ above sea level. The climate in the region is characterized as semiarid. The mean annual temperature is $27.4^{\circ} \mathrm{C}$, while the mean annual rainfall and mean relative humidity are $674 \mathrm{~mm}$ and $68.9 \%$, respectively. Pollen material was dried at $40^{\circ} \mathrm{C}$ for 48 hours and then powdered.

Honeycombs that contained pupae of africanized honey bees (Apis mellifera) were collected from the apiary of UFERSA. Newly emerged forager bees, identified on basis of their body size and coloration, were used for the experiment. All the bees used were of the same age. Twenty bees were put into each wooden box $(11 \times 11 \times 7 \mathrm{~cm})$. The boxes were kept in an acclimatized chamber (BOD) at $32^{\circ} \mathrm{C}$ and $70 \%$ humidity. The basal food was sugar and honey (5:1). M. tenuiflora pollen was added to the food at doses of 0 (control group; $n=195), 2.5 \%$ $(\mathrm{n}=178), 5.0 \%(\mathrm{n}=186)$, and $10.0 \%(\mathrm{n}=186)$. The bees were observed daily until the last one died.

Statistical analyses were performed using the statistical software GraphPad Prism (v.4 for Mac). Median survival times, with $95 \%$ confidence intervals (CI), were estimated using Kaplan-Meier survival analysis. Differences in the time distributions between groups were tested for statistical significance using the log-rank test.

\section{RESULTS}

The median survival times of the bees fed $M$. tenuiflora (Figure 1) were 4 days for all groups. Kaplan-Meier survival analysis revealed a significant difference $(\mathrm{P}=0.0041)$ between the survival curves, but the log-rank test did not show statistical difference $(\mathrm{P}=0.2825)$. The survival curve of controls differed $(\mathrm{P}=0.001)$ from the survival curve of the group fed $2.5 \% \mathrm{M}$. tenuiflora, but did not differ from the other groups.

\section{DISCUSSION}

Secondary plant compounds are well known to affect the quality of plants and to limit growth and reproduction in herbivores. The optimal defense hypothesis postulates that a plant should defend its most valuable parts if resources are limited [10]. Higher concentration of secondary compounds should be found in tissues that are more valuable to the plant. Thus, younger and reproductive tissues are better

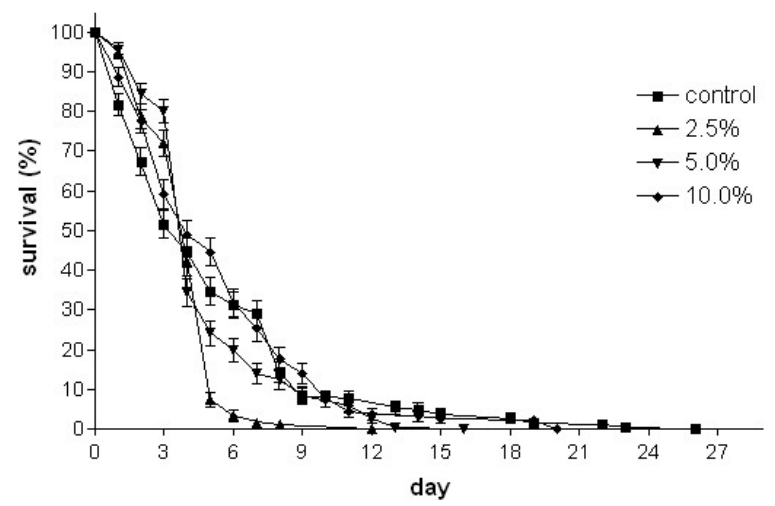

Figure 1. Survival curve (in days) honey bees (Apis mellifera L.) fed food containg 0 (control), 2.5\%, 5.0\%, or $10.0 \%$ of Mimosa tenuiflora (Willd.) Poir. (Mimosaceae) pollen. 
protected than other parts of the plant, because removal of these parts is detrimental to the plant [5].

Several plant species contain secondary compounds in nectar and pollen that could be toxic to pollinators, including bees [1,2,9]. For example, the almond tree (Amygdalus communis L.- Rosaceae) contains the cyanogenic glycoside amygdalin that releases cyanide. Amygdalin is found in the nectar and pollen of almond trees and the consumption of this pollen can be toxic to honey bees [6].

The great majority of flowering plants rely on insects or other animals for pollination, and bees are the most important pollinating insects [11]. The significance of the toxicity of pollen is poorly understood. The function of secondary compounds in nectar has been explained by several hypotheses, including encouragement of specialist pollinators, detention of nectar robbers, prevention of microbial degradation of nectar, disturbance of the behavior of pollinators and the result of previous evolutionary forces that are no longer acting on the plant [2]. With regard to pollen, the relationship between bees and flowers was considered to be one of balanced mutual exploitation. In fact, bees store pollen and nectar to feed their larvae. They collect large amounts of pollen grains very efficiently, making these grains generally unavailable for pollination [11]. Thus, the presence of secondary compounds in pollen grains could be a strategy designed to restrict the loss of pollen to bees. Even though $M$. tenuiflora contains several secondary metabolites, the results of the present study indicate that the pollen of $M$. tenuiflora is not toxic to bees.

\section{CONCLUSIONS}

At conditions of the present study, the ingestion of the pollen of Mimosa tenuiflora by Africanized honey bees (Apis mellifera L.) did not promote toxic effect.

\section{REFERENCES}

1. Adler L.S. 2001. The ecological significance of toxic nectar. Oikos. 91 (3): 409-420.

2. Adler L.S. \& Irwin R.E. 2005. Ecological costs and benefits of defenses in nectar. Ecology. 86 (11): 2968-2978.

3. Jiang Y., Massiot G., Lavaud C., Teulon J.M., Guechot C., Haag M. \& Anton R. 1991. Triterpenoid glycosides from the bark of Mimosa tenuiflora. Phytochemistry. 30 (7): 2357-2360.

4. Jiang Y., Massiot G., Lavaud C., Teulon J.M., Guechot C., Haag M. \& Anton R. 1991. Structure of a new saponin from the bark of Mimosa tenuiflora. Journal of Natural Products. 54 (5): 1247-1253.

5. Karban R. \& Baldwin I.T. 1997. Induced Responses to Herbivory. Chicago: University of Chicago Press, 330pp.

6. Kevan P.G. \& Ebert T. 2005. Can almond nectar and pollen poison honey bees? American Bee Journal. 145 (6): 507-509.

7. Ohsaki A., Yokoyama R., Miyatake H. \& Fukuyama Y. 2006. Two Diterpene Rhamnosides, Mimosasides B and C, from Mimosa hostilis. Chemical \& Pharmaceutical Bulletin. 54 (12): 1728-1729.

8. Pimentel L.A., Riet-Correa F., Gardner D., Panter K.E., DantasA.F.M., Medeiros R.M.T., Mota R.A. \& Araújo J.A.S. 2007. Mimosa tenuiflora as a cause of malformations in ruminants in the Northeastern Brazilian semiarid rangelands. Veterinary Pathology. 44 (6): 928-931.

9. Praz C.J., Müller A. \& Dorn S. 2008. Specialized bees fail to develop on non-host pollen: do plants chemically protect their pollen? Ecology. 89 (3): 795-804.

10. Rhoades D.F. 1979. Evolution of plant chemical defence against herbivores. In: Rosenthal G.A. \& Janzen D.H. (Eds.). Herbivores: their interaction with secondary plant metabolites. New York: Academic Press, pp. 3-54.

11. Westerkamp C. 1996. Pollen in bee-flower relations. Some considerations on melittophily. Botanica Acta. 109 (4): $325-$ 332. 
